\title{
Implication of microRNA as a potential biomarker of myocarditis
}

\author{
Jin-Hee Oh, MD, PhD' ${ }^{1}$ Gi Beom Kim, MD², Heeyoung Seok, PhD ${ }^{3}$
}

${ }^{1}$ Department of Pediatrics, St. Vincent's Hospital, College of Medicine, The Catholic University of Korea, Seoul, Korea; ${ }^{2}$ Department of Pediatrics, Seoul National University Children's Hospital, Seoul National University College of Medicine, Seoul, Korea; ${ }^{3}$ Department of Transdisciplinary Research and Collaboration, Genomics Core Facility, Biomedical Research Institute, Seoul National University Hospital, Seoul, Korea

Myocarditis was previously attributed to an epidemic viral in fection. Additional harmful reagents, in addition to viruses, play a role in its etiology. Coronavirus disease 2019 (COVID-19) vaccine-induced myocarditis has recently been described, drawing attention to vaccine-induced myocarditis in children and adolescents. Its pathology is based on a series of complex immune responses, including initial innate immune responses in response to viral entry, adaptive immune responses leading to the development of antigen-specific antibodies, and autoimmune responses to cellular injury caused by cardiomyocyte rupture that releases antigens. Chronic inflammation and fibrosis in the myocardium eventually result in cardiac failure. Recent advancements in molecular biology have remarkably increased our understanding of myocarditis. In particular, microRNAs (miRNAs) are a hot topic in terms of the role of new biomarkers and the pathophysiology of myocarditis. Myocarditis has been linked with microRNA-221/222 (miR-221/222), miR-155, miR-10a*, and miR-590. Despite the lack of clinical trials of miRNA intervention in myocarditis yet, multiple clinical trials of miRNAs in other cardiac diseases have been aggressively conducted to help pave the way for future research, which is bolstered by the success of recently U.S. Food and Drug Administration-approved small-RNA medications. This review presents basic information and recent research that focuses on myocarditis and related miRNAs as a potential novel biomarker and the therapeutics.

Key words: Myocarditis, Heart, MicroRNA, Circulating, Biomarker, RNA medication

\section{Key message}

- Myocarditis was recently examined quantitatively as inflammation of the heart muscle based on endomyocardial biopsy, and its noninvasive diagnosis remains unsatisfactory.

- Additionally, numerous miRNAs (miR-155, miR-146b, miR590, miR-221, miR-222, etc.) coupled with inflammation or viral activation have been examined in myocarditis patients or mouse models.

- The recent identification of mmu-miR-721 (has-miR-Chr8: 96), a myocarditis-specific microRNA, demonstrated its potential as an acute myocarditis biomarker.

\section{Introduction}

Myocarditis is a broad term for inflammatory disorders of the heart muscles. In his work, Traité des Maladies du Coeur (Treatise on Heart Disease) published in 1749, Jean Baptiste Senac identified inflammation in the heart. Later, Joseph Freidrich Sobernheim coined the term myocarditis to describe cardiomyopathy caused by myocyte inflammation, ischemia, and hypertensive heart disease. ${ }^{1)}$ Various viral infections in the heart, such as coxsackievirus, echovirus, the mumps virus, influenza virus, measles virus, poliovirus, and smallpox, have been reported during epidemic periods, leading to myocarditis becoming a broader term that covers myocardial infarction, chronic ischemic heart disease, and occasionally, pancarditis or myopericarditis. ${ }^{2,3)}$ To date, it has been used interchangeably. Recent efforts have been made to clearly describe myocarditis, which is defined as inflammation of the cardiac muscle and recognized as a disease that leads to heart failure. ${ }^{1,4)}$

Endomyocardial biopsy (EMB) with quantitative standards ( $\geq 14$ lymphocytes $/ \mathrm{mm}^{2}$, including $\leq 4$ monocytes $/ \mathrm{mm}^{2}$, with the presence of cluster of differentiation 3-positive $\mathrm{T}$ lymphocytes, 7 cells $/ \mathrm{mm}^{2}$ ) and immunohistochemistry assays are used to diagnose myocarditis. ${ }^{3,5)}$ However, this approach is only acceptable for isolated inflammatory regions, making it difficult to diagnose fulminant myocarditis (FM), which involves widespread inflammation throughout the heart.6,7) Quantitative cardiac troponin analysis combined with cardiac magnetic resonance imaging (MRI) to assess the injured myocardium can be utilized to noninvasively diagnose myocarditis to overcome localized inflammation, spontaneous resolution, and myocar-

\footnotetext{
Corresponding author: Heeyoung Seok, PhD. Department of Transdisciplinary Research and Collaboration, Genomics Core Facility, Biomedical Research Institute, Seoul National University Hospital, Rm3209, Center for Medical Innovation (CMI), 128 Yeongeon-dong Jongno-Gu, Seoul 03080, Korea

凶Email: hyseok@snuh.org, https://orcid.org/0000-0003-2699-9935

Received: 5 December, 2021, Revised: 22 January, 2022, Accepted: 29 January, 2022

This is an open-access article distributed under the terms of the Creative Commons Attribution Non-Commercial License (http://creativecommons.org/licenses/by$\mathrm{nc} / 4.0 /$ ) which permits unrestricted non-commercial use, distribution, and reproduction in any medium, provided the original work is properly cited.

Copyright (c) 2022 by The Korean Pediatric Society
} 


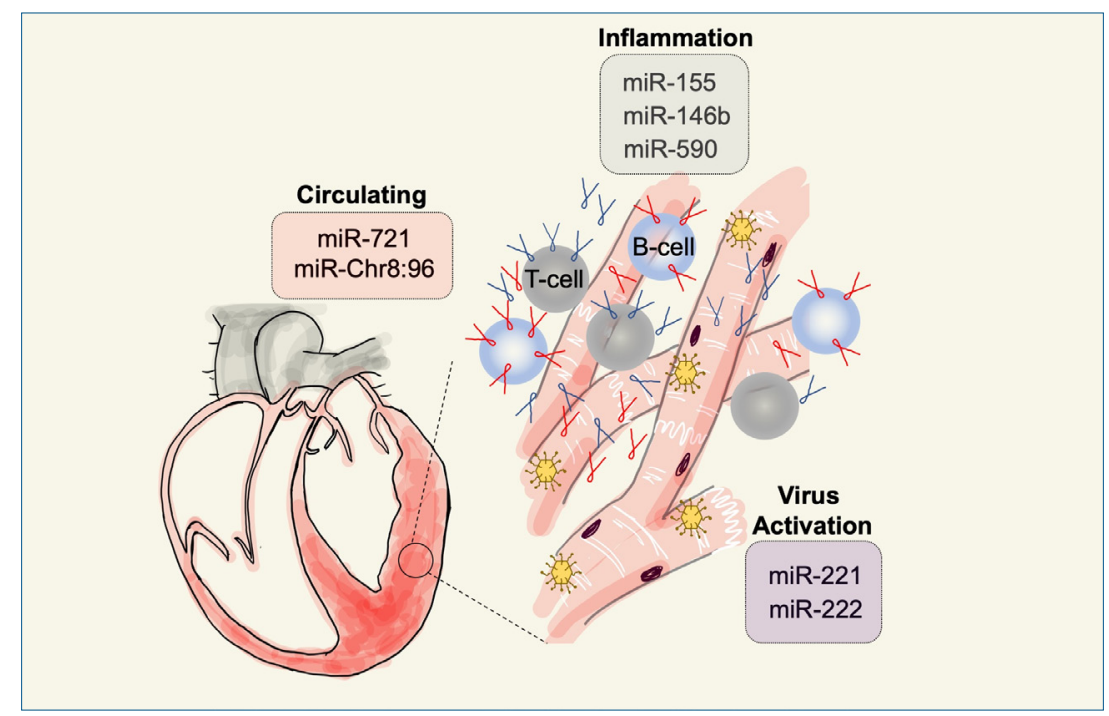

Graphical abstract

dium sampling difficulties. ${ }^{8-11)}$

According to the International Classification of Illnesses 9th revision, myocarditis affects approximately 22 per 100,000 individuals worldwide. ${ }^{12,13)}$ Systematic reviews of the clinical courses of myocarditis patients from the Lombardy registry (443 patients from the Italian region) and 220 cases in 2018, which used combined diagnostic strategies, revealed that left ventricular systolic dysfunction, ventricular arrhythmias, hemodynamic instability, and QRS width should be considered the initial diagnostic factors for FM. ${ }^{14,15)}$

An estimated, $0.5 \%-4 \%$ of myocarditis cases progress to heart failure. ${ }^{13)}$ Myocarditis, which is the leading cause of sudden death among young athletes, is particularly prevalent, accounting for $5 \%-12 \%$ of all deaths. ${ }^{16}$ ) Furthermore, our understanding of the etiology of myocarditis is limited, although we know that it can occasionally resolve spontaneously or result in heart failure, highlighting the need for early diagnosis and accurate comprehension. ${ }^{4)}$

This review presents basic information and recent research highlights in the field of myocarditis, with a particular focus on disease-specific microRNA (miRNA) expression patterns and the goal of their potential use as alternative prognostic and diagnostic tools to supplement the current standards.

\section{Myocarditis etiology}

Infection, autoimmune responses, and toxicity are the 3 most common causes of myocarditis. Among them, viral infections are the most common. Several viruses, including coxsackievirus, ${ }^{17,18)} \mathrm{H} 1 \mathrm{~N} 1$ influenza, ${ }^{19)}$ adenovirus, ${ }^{20)}$ hepatitis $\mathrm{C},{ }^{21,22)}$ cytomegalovirus, ${ }^{23)}$ echovirus, ${ }^{24)}$ parvovirus B-19, herpes virus, ${ }^{25}$ and Epstein-Barr virus ${ }^{26}$ were detected in heart autopsy samples on a regular and local basis. ${ }^{26)}$ In addition to viral infectionmediated immune responses, bacterial-driven cases such as Lyme disease (Borrelia burgdorferi) ${ }^{27)}$ and parasite-mediated Chagas disease (Trypanosoma cruzi) ${ }^{28)}$ have been reported regularly, as have drug- or vaccine-related cases such as ampicillin or tetracycline ${ }^{29-31)}$ or smallpox vaccines..$^{32,33)}$

Amid the recent coronavirus disease 2019 (COVID-19) pandemic, cases of myocarditis reported in people vaccinated with the COVID-19 mRNA vaccine and the relationship between myocarditis after COVID-19 infection and vaccination are under investigation. This finding was supported by 2 major cohort studies. One survey in Israel reported 136 cases of definitive or probable myocarditis within one month of receiving one shot of the vaccine. This study included more than 5 million participants who had received immunization. Of these cases, 135 had a mild or moderate clinical course and one was fatal. After the second dose of the vaccination, a 15 in 100,000 chance of developing myocarditis was assessed in adolescents and young men aged $16-19$ years. $^{30)}$ Similar studies in the United States reported a somewhat lower rate of 5 of 10,000 cases (18- to 24-year-old men). However, all of these cases were less severe than myocarditis caused by direct viral infection. Severe acute respiratory syndrome coronavirus 2 infection results in an 18fold increased risk of myocarditis in the same age group. ${ }^{31)}$

Two 10-year studies of Koreans included cases of myocarditis in children. Park et al. ${ }^{34)}$ studied the incidence of myocarditis in Korean children in 2010-2019. This multicenter study included 142 patients with myocarditis/pericarditis. The patients were a mean 5.4 years of age, with males accounting for $61 \%$ of the total. Compared to other age groups ranging from 17 days to 17 years of age, the teen years, defined as ages 12-17 years, had the highest prevalence of 1.25 per 1,000 patients. The frequency of occurrence has increased considerably over the last decade from 0.34 in 2010 to 1.25 in 2019. Among the principal etiologies of infections are Mycoplasma pneumoniae, enterovirus, rhinovirus, adenovirus, respiratory syncytial virus, influenza virus, parainfluenza virus, and parvovirus. On rare occasions, adenoviruses and endemic coronaviruses have been observed simultaneously. However, in $60 \%$ of patients, no pathogens were 
detected. Between 2007 and 2016, another study enrolled 1,462 pediatric cases after health insurance evaluations. The annual occurrence has increased from 1.4 to 2.1. Male patients over the age of 13 years were much more numerous in the 2010-2019 survey. ${ }^{35)}$ The incidence of myocarditis is bimodal, with peaks during infancy and midadolescence, similar to the 2 peaked cardiac growth signals. ${ }^{36,37)}$ These 2 studies reported a similar trend of myocarditis in Korean children: (1) Its proclivity for growth continues to increase annually; and (2) In midadolescence, boys are more prone to its development.

In Korea, COVID-19 vaccinations for third-year high school students began in July 2021. The incidence of myocarditis was calculated. Myocarditis occurred in 1.97 of every 100,000 cases after the first dose and 3.1 of every 100,000 cases after the second dose per 100,000 vaccine cases. These data were provided concurrently with the incidence in the United States and Israel based on a report from Korea's Disease Control and Prevention Agency (12-9-21 release). According to this report, myocarditis cases in Korea are approximately 7 times higher than that described in the United States or 3 times more than that in Israel for the first dose. However, the incidence after the second immunization dose was comparable to or lower than that of other 2 countries. Notably, Israel's incidence following the second dose is 2.77 times higher than that in Korea. Table 1 illustrates a three-nation comparison focusing on midadolescent age cases of the myocarditis after vaccinations.

\section{Myocarditis pathogenesis}

Because viral infection is the most common cause of myocarditis, viral infection-mediated pathology is discussed here. These studies are mostly based on the pathophysiological understanding of the murine model. The first step is linked to viral replication in the heart, resulting in cellular rupture, an antigenindependent and innate immune response. Consequently, adaptive immune responses are triggered in antigen-presenting cells, resulting in the production of antigen-specific antibodies. Autoimmune reactions and cellular damage propagate during this stage as cardiac proteins are released through cardiomyocyte rupture. Finally, the replacement of collagen with dead myocardium results in persistent inflammation and fibrosis. ${ }^{38)}$

There is also disagreement regarding whether viral infection

Table 1. Myocarditis occurrence comparison (Korea, USA, and Israel)

\begin{tabular}{lcc}
\hline Nation (age/update date) & \multicolumn{2}{c}{$\begin{array}{c}\text { Myocarditis/pericarditis cases } \\
\text { (unit: case/ } 100,000 \text { vaccinations) }\end{array}$} \\
\cline { 2 - 3 } & 1st dose & 2nd dose \\
\hline Korea (18/2021.12.9) & 1.97 & 3.1 \\
USA (16-17/2021.8.30) & 0.25 & 3.4 \\
Israel $(16-19 / 2021.11 .17)^{\mathrm{c})}$ & 0.6 & 8.6 \\
\hline
\end{tabular}

${ }^{a)}$ Korea Disease Control and Prevention Agency report, 12-9-21. ${ }^{\text {b) } A C I P, ~ C D C ~}$ COVID-19 Vaccine Task Force, 2021.8.30. ${ }^{c}$ Vaccine warning and booster protection across age, data from Israel, 2021.11.17. is a direct pathogenic cause of cardiac injury. It is a situation in which a virus triggers immune responses to cause cardiomyocyte injury, or that cardiomyocyte injury is caused by viral infection. The presence of the viral genome in the myocardium of patients with chronic inflammatory cardiomyopathy, rather than acute myocarditis, is suggested. ${ }^{39,40)}$ Reports on FM associated with viral infection frequently adopted nasopharyngeal swabs for the diagnosis of viral infection. ${ }^{41)}$ The hs-troponin level was also elevated in COVID-19 patients, suggesting that the virus generated aberrant immune-mediated inflammatory responses rather than viral-directed myocyte damage. ${ }^{42-44)}$ Understanding the pathophysiology, whether the virus is directly or indirectly involved, is critical for immunosuppression because its role is also conflicting. ${ }^{3,45)}$ The use of immunosuppressive medication should generally be validated by polymerase chain reaction to ensure that the condition is not an active infection in EMB.3)

Patients with acute myocarditis alone or in combination with autoimmune responses were also identified among those who received immuno-checkpoint inhibitor (ICI) medications. ${ }^{46,47)}$ Since many cancer patients have just begun to utilize ICI treatment and its estimated correlation with myocarditis is $1.14 \%$, it may become a subtype of myocarditis with distinct age and inflammatory type in the near future. ${ }^{46)}$

\section{Myocardial inflammation and the cellular compartment}

Idiopathic, autoimmune, and infectious are the 3 types of myocardial inflammation. ${ }^{4)}$ Interactions between several cellular compartments causes myocardial inflammation. T-, B-, and lymphoid-derived cells, such as macrophages, dendritic cells, granulocytes, mast cells, and immature precursor cells, all contribute to the differentiation of inflammatory cells and myofibroblasts. ${ }^{4}$ Caspase-1, n-terminal PYRIN PAAD DAPIN and c-terminal caspase-recruitment domain containing, and nucleotide-binding oligomerization domain-like receptor pathways play a role in the production of proinflammatory cytokines during this process. Toll-like receptors (TLRs) have also been implicated in the activation of innate immune responses in the early stages. ${ }^{48)}$ TLR3 polymorphism have been linked to enteroviral myocarditis. ${ }^{49)}$ Tumor necrosis factor- $\alpha(\mathrm{TNF}-\alpha)$ and interleukin (IL)- $1 \beta$ are also released in the myocardium by the TLR pathway. ${ }^{50,51)}$

Inflammatory cell invasion is aided by macrophages. Because Ly6Chi inflammatory macrophages are found in the early stages of cardiac damage, their blockade has been used to treat autoimmune myocarditis. ${ }^{52-54)}$ The Ly6Clow M2 macrophage is a critical factor in the transition from acute to pathological remodeling via myofibroblast replacement. ${ }^{55,56)}$ Thymic resistance to alpha-myosin heavy chain $(\mathrm{MyHC})$ causes, at least in part, T-cell function to quell autoimmune responses after clearing infections. ${ }^{57,58)}$ Overexpressing alpha-MyHC promoterspecific T-cell receptors were designed for a mouse autoimmune 
myocarditis model based on this understanding. ${ }^{59)}$ The release of cytokines by $\mathrm{T}$ cells determines myocarditis progression. T-helper (Th) type 1 cells produce interferon gamma, while Th2 cells produce IL-4, -5 , and -13 . Type 17 helper T (Th17) cells

Table 2. Etiology of myocarditis

\begin{tabular}{|c|c|c|}
\hline Etiology & Pathogenesis & Reference \\
\hline \multicolumn{3}{|l|}{ Virus } \\
\hline Coxsackie & Viral replication & 17,18 \\
\hline H1N1 strains of influenza & & 19 \\
\hline Hepatitis C & & 21,22 \\
\hline Adenovirus & & 20 \\
\hline Cytomegalovirus & & 23 \\
\hline Echovirus & & 24 \\
\hline Epstein-Barr virus & & 26 \\
\hline Parvovirus B19 & & 25 \\
\hline Human herpes virus 6 genome & & 25 \\
\hline \multicolumn{3}{|l|}{ Bacteria } \\
\hline Borrelia burgdorferi (Lyme diseases) & & 27 \\
\hline \multicolumn{3}{|l|}{ Parasite } \\
\hline Trypanosoma cruzi (Chagas diseases) & $\begin{array}{l}\text { Inflammatory/ } \\
\text { oxidative stress }\end{array}$ & 28 \\
\hline \multicolumn{3}{|l|}{ Drug } \\
\hline \multicolumn{3}{|l|}{ Phenytoin } \\
\hline \multicolumn{3}{|l|}{ Hydrochlorothiazide } \\
\hline \multicolumn{3}{|l|}{ Furosemide } \\
\hline Ampicillin & & 28 \\
\hline \multicolumn{3}{|l|}{ Tetracycline } \\
\hline \multicolumn{3}{|l|}{ Azithromycin } \\
\hline \multicolumn{3}{|l|}{ Aminophylline } \\
\hline \multicolumn{3}{|l|}{ Phenytoin } \\
\hline \multicolumn{3}{|l|}{ Benzodiazepines } \\
\hline \multicolumn{3}{|l|}{ Tricyclic antidepressants } \\
\hline \multicolumn{3}{|l|}{ Tumor necrosis factor antagonists } \\
\hline \multicolumn{3}{|l|}{ Vaccine } \\
\hline Smallpox & & 32,33 \\
\hline COVID 19 & & 30,31 \\
\hline
\end{tabular}

mainly produce IL-17. ${ }^{60-63)}$

While lymphoid-derived cells are involved in adaptive immune responses, endothelial cells act as barriers preventing circulating bone marrow-derived cells from entering the heart. Interstitial cell types, such as fibroblasts, myofibroblasts, and stromal cells, act as a matrix to modify the inflammatory phenotype via local cues. During pathogenesis, the cardiomyocyte compartment is also involved in early infection and adaptive responses such as altered calcium signaling or hypertrophy. ${ }^{64,65)}$ Both direct and indirect cross-talk was used to orchestrate these interactions (Table 2). ${ }^{66)}$

\section{Myocarditis and miRNA}

There has been research on the posttranscriptional modulation of cardiac immunological responses, including miRNAmediated controls. MiRNAs are 22-nt single-strand RNAs that complementarily base pair with mRNAs, primarily but not exclusively in the 3 ' untranslated region, to govern translation by a minimum 6-mer base-pairing. This is generally a translational repressor. ${ }^{67,68)}$

The importance of miRNAs in myocardial specification and cardiac development, as well as in cardiac disorders such as cardiac hypertrophy, myocardial infarction, arrhythmia, myocarditis, coronary artery disease, and heart failure, has been recognized. ${ }^{69-71)}$ Circulating miRNAs in the blood have been used to identify novel biomarkers in addition to their role in the heart. ${ }^{72,73)}$ MED13 and miR-208a are 2 of the most notable regulators of metabolic homeostasis via systemic control. ${ }^{74)}$ Table 3 summarizes the miRNAs in heart disorders, including myocarditis.

Several miRNA profiling studies have been conducted. A total of 107 miRNAs were dysregulated in human right ventricular myocarditis samples. ${ }^{75)}$ The inhibition of miR-155, miR-21, and miR-146b, for example, reduced cardiac inflammation and myocardial damage in a coxsackievirus B3 (CVB3) animal model and mouse autoimmune studies. ${ }^{76-79)}$ Furthermore, miR-

Table 3. MiRNAs correlated with myocarditis

\begin{tabular}{|c|c|c|c|}
\hline miRNA & Expected target & Category & Reference \\
\hline $\mathrm{miR}-221 / 222$ & ETS1/2, irf2, BCL2L1, TOX, BMF, CXCL12 & Activation of CVB3 & 84 \\
\hline miR-203 & ZFP-148 & Cell survival & 1 \\
\hline miR-141 & elF4E & Viral translation/cellular translation & 102 \\
\hline miR-10a* & CVB3 nt6818-6941 & Viral biosynthesis & 103,104 \\
\hline $\mathrm{miR}-21$ & YOD1, VCL & Desmin/desmosome/cadherin & 79 \\
\hline miR-1 & Connection-43 & Gap junction & 105 \\
\hline miR-126 & LRP6, WRCH1 & Cell death & 106 \\
\hline miR-155 & PU.1 & Inflammation, virus replication & 76,85 \\
\hline $\mathrm{miR}-146 \mathrm{~b}$ & IRAK1, TRAF6 & Inflammation & 79,107 \\
\hline miR-142 & MBD2, SOCS1 & Immuno-metabolic turbulence & 108 \\
\hline miR-590 & NF-kB/p50 subunit & Inflammation & 80 \\
\hline mmu-miR-721/has-miR-Chr8:96 & Ppary, Nos2, Stat3, Tgfß, and Cd69 & Early response & 86 \\
\hline
\end{tabular}

CVB3, coxsackievirus B3; miRNA, microRNA. 
590-3p overexpression reduced disease by repressing nuclear factor kappa B (NF- $\kappa \mathrm{B})$ expression and turning off IL-6/TNF- $\alpha$ expression by targeting NF- $\kappa \mathrm{B} .{ }^{80}$ )

Patients with myocarditis were profiled for various CVB3 clearance conditions. Patients with defective cardiac function under protracted viral accumulation (CVB3) had a greater expression of 8 miRNAs, including miR-135b, -155, -190, $-422 \mathrm{a},-489,-590,-601$, and $-1290 .^{81)}$ Circulating miRNAs in the blood have been investigated as a means of diagnosis or prognosis, while myocarditis is present. miR-208 and miR-499 were overexpressed in the blood plasma during acute myocarditis. However, misregulation of these 2 miRNAs has been documented in acute ischemia and hypertensive disorders, implying that other defining factors may be required. ${ }^{82,83)}$ Cellular release in response to inflammation could explain the mixed expression of these 2 miRNAs. ${ }^{82}$

In mouse myocarditis model studies involving enterovirus CVB3, the dysregulation of miR-221/222 by targeting ETS1/2, interferon regulatory factor 2 , and B-cell lymphoma 2 (Bcl2)like-11 maintained prolonged cardiac viremic states and activate inflammatory and injury pathways by targeting ETS1/2, interferon regulatory factor 2 , and $\mathrm{Bcl} 2$-like-11. ${ }^{84)} \mathrm{MiR}-155$ uses a similar regulatory mechanism to activate immune responses such as T cells and monocytes by targeting PU.1 and suppressor of cytokine signaling $1 .^{84,85)}$

Recent studies using a murine myocarditis model revealed the induction of cardiac myosin-specific Th17 lymphocytes in a myocarditis-specific manner, turning on as early as 3 days after onset, which differs from the response of myocardial infarction, which also showed Th17 cell upregulation later in the disease course. Using a murine model, the authors validated Th17 cell upregulation of mmu-miR-721 from 27 dysregulated miRNAs. The authors stated that dysregulation of the human version of miR-721, has-miR-Chr8:96, was confirmed in a large human cohort study that included 42 myocarditis patients (based on cardiac MRI diagnosis), 90 myocardial infarction patients, and 80 healthy participants, implying that it could be used as a biomarker for acute myocarditis. ${ }^{86)}$

A total of 113 miRNAs were differentially expressed in a murine myocarditis model using Trypanosoma cruzi. The authors reported that miR-146b, miR-21, miR-142-3p, miR142-5p, miR-145-5p, and miR-149-5p were correlated with disease severity. ${ }^{79)}$

\section{MiRNAs as medications for cardiac diseases}

Although antisense RNAs as a novel mechanism for medication have been explored since $1978,{ }^{87)}$ the success of partisiran, a short RNA drug that mimics siRNAs with pharmacological features to treat polyneuropathy, has only recently become beneficial for treatment. ${ }^{88-90)}$

Small RNA therapies, either inhibiting or activating, are likely to be actively developed for the medical intervention of

Table 4. Clinical trials of miRNAs and cardiac diseases

\begin{tabular}{|c|c|c|c|c|c|}
\hline NCT No. & Conditions & Outcome measures & Phases & Enrollment & Status \\
\hline NCT02850627 & $\begin{array}{l}\text { Coronary heart disease } \\
\text { Acute myocardial infarction }\end{array}$ & $\begin{array}{l}\text { miRNAs spectrum } \\
\text { Major adverse cardiac event } \\
\text { Renin predicts cardiovascular homeostasis and ventricular remodeling } \\
\text { Ang II predicts cardiovascular homeostasis and ventricular } \\
\text { remodelinglserum E } \\
\text { Inflammatory mediators } \\
\text { Brain natriuretic peptide } \\
\text { Echocardiography measure of left ventricular systolic function } \\
\text { Echocardiography measure of left ventricular diastolic function } \\
\text { New York Heart Association functional classification } \\
\text { Coronary angiography } \\
\text { Seattle Angina Questionnaire score } \\
\text { The traditional Chinese medicine syndrome scale }\end{array}$ & Phase 4 & 100 & $\begin{array}{l}\text { Unknown } \\
\text { status }\end{array}$ \\
\hline NCT01615003 & $\begin{array}{l}\text { Coronary heart disease } \\
\text { Unstable angina } \\
\text { Blood stasis syndrome }\end{array}$ & $\begin{array}{l}\text { The change of cycle threshold of relational microRNA in coronary } \\
\text { artery disease with unstable angina }\end{array}$ & Phase 2 & 70 & $\begin{array}{l}\text { Unknown } \\
\text { status }\end{array}$ \\
\hline NCT04950569 & Heart failure & $\begin{array}{l}\text { NT-proBNP } \\
\text { miR-660-3p, miR- } 665 \text { and miR-1285-3p } \\
\text { Left ventricular ejection fraction } \\
\text { NYHA } \\
6 \text { Minutes walking distance }\end{array}$ & Phase 4 & 136 & Recruiting \\
\hline NCT03083119 & $\begin{array}{l}\text { Coronary heart disease } \\
\text { Unstable angina }\end{array}$ & $\begin{array}{l}\text { Major adverse cardiovascular events } \\
\text { Seattle Angina Questionnaire } \\
\text { Blood stasis syndrome scale of coronary heart disease angina pectoris } \\
\text { Lipid }\end{array}$ & Phase 2 & 70 & $\begin{array}{c}\text { Unknown } \\
\text { status }\end{array}$ \\
\hline NCT02447809 & Coronary artery disease & $\begin{array}{l}\text { The expressions of miRNAs profile } \\
\text { Clinical efficacy }\end{array}$ & Phase 4 & 400 & $\begin{array}{l}\text { Unknown } \\
\text { status }\end{array}$ \\
\hline NCT02071966 & $\begin{array}{l}\text { Non-ST segment elevation } \\
\text { Acute coronary syndrome }\end{array}$ & MicroRNA and microparticles & Phase 4 & 55 & Terminated \\
\hline
\end{tabular}

NCT, the national clinical tria; miRNA, microRNA; NT-proBNP, N-terminal pro-brain natriuretic peptide; NYHA, New York Heart Association. 
heart disorders. ${ }^{90-93)}$ In the pharmaceutical industry, there are 2 primary types of antitechnologies that repress miRNAs. The first is antagomir, ${ }^{94)}$ a cholesterol-based modified RNA, while the second is locked nucleic acid (LNA)-modified RNA. ${ }^{70,95)}$ AntimiR-92a, also known as MRG-110, is an LNA/DNA mixed, phosphorothiorate linkage, and 16-nucleic acid medication that was administered intravenously and had a repressive efficacy of up to 2 weeks with a single dose in healthy humans. ${ }^{96}$ Taubel et al. ${ }^{97)}$ used an antisense LNA method to block miR-132-3p in patients with heart failure. This group previously demonstrated that LNA-based chemical modification approaches effectively lowered miRNA levels while maintaining Watson-Crick basepairing. ${ }^{98)}$

Furthermore, scientists demonstrated that miR-132-3p repression clearly improved the heart failure mouse model, ${ }^{99}$ ) which was then expanded into a large animal setting as a preclinical trial to determine the dosage with enhanced cardiac functions. ${ }^{100)}$ With this excellent research background, the authors assessed the efficacy of LNA-miR-132-3p (CDR132L) for the first time by examining heart failure biomarkers, cardiac fibrosis, QRS narrowing, and left ventricular ejection fraction. For 28 patients, 4 dosage groups with a maximum dose of 10 $\mathrm{mg} / \mathrm{kg}$ administered every 4 weeks were created. Efficacy assessments were underpowered in the phase $1 \mathrm{~b}$ trial due to the research design and small patient cohort, but this study clearly demonstrated the safety of a dose-dependent reduction of plasma miR-132-3p expression level and encouraged the next stage in the development of this innovative drug. ${ }^{97)}$

\section{MiRNAs as biomarkers for cardiac diseases}

In both experimental animals and humans, miRNA expression profiling has been shown to reflect disease status and/ or progression. Misregulation of miR-195 and miR-21 was observed for the first time in mouse models of heart hypertrophy. ${ }^{101)}$ Since then, a large amount of miRNA profiling data has been amassed in various cardiovascular disease models and patients, leading to current active clinical trials. ${ }^{73)}$ In heart failure patients, for example, profiling miRNA expression as biomarkers from patients receiving U.S. Food and Drug Administration (FDA)-approved medications has been described. Table 4 contains detailed information on miRNA investigations in clinical trials.

\section{Conclusion}

Myocarditis remains a challenge, and the recent COVID-19 outbreak has brought it back to the forefront. Although its exact pathophysiology remains unknown, new research is seeking to improve our understanding and lay the groundwork for newer treatment methods. MiRNAs offer further insights into this understanding.
Over the past several years, miRNA studies on cardiac diseases have been ongoing. There are 6 records of miRNAs in coronary heart disorders, myocardial infarction, heart failure, and unstable angina on the clinical trial list, spanning early phases $1-4$. There were 40 studies on miRNAs in heart disorders if the searches were widened to include non-FDA-defined phase trials. To date, no direct clinical studies have investigated miRNAs in myocarditis; nevertheless, the role of miRNAs has been investigated and specific miRNAs have been identified, paving the way for future innovative interventions and/or diagnostics.

\section{Footnotes}

Conflict of interests: There is no conflict of interests to declare.

Funding: This work is supported by NRF-2020R1A2C1013377 and NRF-2017R1D1A1B03030852 for H Seok.

ORCID:

Jin-Hee Oh @ http://orcid.org/0000-0002-2893-0563

Gi Beom Kim @ http://orcid.org/0000-0002-7880-280X

Heeyoung Seok $@$ https://orcid.org/0000-0003-2699-9935

\section{References}

1. Fung G, Luo H, Qiu Y, Yang D, McManus B. Myocarditis. Circ Res 2016;118:496-514.

2. Dennert R, Crijns HJ, Heymans S. Acute viral myocarditis. Eur Heart J 2008;29:2073-82.

3. Caforio AL, Pankuweit S, Arbustini E, Basso C, Gimeno-Blanes J, Felix SB, et al. Current state of knowledge on aetiology, diagnosis, management, and therapy of myocarditis: a position statement of the European Society of Cardiology Working Group on Myocardial and Pericardial Diseases. Eur Heart J 2013;34:2636-48, 2648a-2648d.

4. D'Ambrosio A, Patti G, Manzoli A, Sinagra G, Di Lenarda A, Silvestri F, et al. The fate of acute myocarditis between spontaneous improvement and evolution to dilated cardiomyopathy: a review. Heart 2001;85:499-504.

5. Aretz HT. Myocarditis: the Dallas criteria. Hum Pathol 1987;18:619-24.

6. Kociol RD, Cooper LT, Fang JC, Moslehi JJ, Pang PS, Sabe MA, et al. Recognition and initial management of fulminant myocarditis: a scientific statement from the American Heart Association. Circulation 2020;141:e69-92.

7. Chow LH, Radio SJ, Sears TD, McManus BM. Insensitivity of right ventricular endomyocardial biopsy in the diagnosis of myocarditis. J Am Coll Cardiol 1989; 14:915-20.

8. Anzini M, Merlo M, Sabbadini G, Barbati G, Finocchiaro G, Pinamonti B, et al. Long-term evolution and prognostic stratification of biopsy-proven active myocarditis. Circulation 2013;128:2384-94.

9. Kindermann I, Kindermann M, Kandolf R, Klingel K, Bultmann B, Muller T, et al. Predictors of outcome in patients with suspected myocarditis. Circulation 2008;118:639-48.

10. Caforio AL, Calabrese F, Angelini A, Tona F, Vinci A, Bottaro S, et al. A prospective study of biopsy-proven myocarditis: prognostic relevance of clinical and aetiopathogenetic features at diagnosis. Eur Heart J 2007; 28:1326-33

11. Vaidya VR, Abudan AA, Vasudevan K, Shantha G, Cooper LT, Kapa $\mathrm{S}$, et al. The efficacy and safety of electroanatomic mapping-guided endomyocardial biopsy: a systematic review. J Interv Card Electrophysiol 
2018;53:63-71.

12. Global Burden of Disease Study C. Global, regional, and national incidence, prevalence, and years lived with disability for 301 acute and chronic diseases and injuries in 188 countries, 1990-2013: a systematic analysis for the Global Burden of Disease Study 2013. Lancet 2015;386: 743-800.

13. Cooper LT Jr, Keren A, Sliwa K, Matsumori A, Mensah GA. The global burden of myocarditis: part 1: a systematic literature review for the Global Burden of Diseases, Injuries, and Risk Factors 2010 study. Glob Heart 2014;9:121-9.

14. Ammirati E, Cipriani M, Moro C, Raineri C, Pini D, Sormani P, et al. Clinical presentation and outcome in a contemporary cohort of patients with acute myocarditis: multicenter lombardy registry. Circulation 2018; 138:1088-99.

15. Ammirati E, Veronese G, Brambatti M, Merlo M, Cipriani M, Potena L, et al. Fulminant versus acute nonfulminant myocarditis in patients with left ventricular systolic dysfunction. J Am Coll Cardiol 2019;74:299-311.

16. Maron BJ, Udelson JE, Bonow RO, Nishimura RA, Ackerman MJ, Estes NA 3rd, et al. Eligibility and disqualification recommendations for competitive athletes with cardiovascular abnormalities: Task Force 3: hypertrophic cardiomyopathy, arrhythmogenic right ventricular cardiomyopathy and other cardiomyopathies, and myocarditis: a scientific statement from the American Heart Association and American College of Cardiology. Circulation 2015;132:e273-80.

17. Pauschinger M, Phan MD, Doerner A, Kuehl U, Schwimmbeck PL, Poller W, et al. Enteroviral RNA replication in the myocardium of patients with left ventricular dysfunction and clinically suspected myocarditis. Circulation 1999;99:889-95.

18. Andreoletti L, Leveque N, Boulagnon C, Brasselet C, Fornes P. Viral causes of human myocarditis. Arch Cardiovasc Dis 2009;102:559-68.

19. Baruteau AE, Boimond N, Ramful D. Myocarditis associated with 2009 influenza A (H1N1) virus in children. Cardiol Young 2010;20:351-2.

20. Bowles NE, Ni J, Kearney DL, Pauschinger M, Schultheiss HP, McCarthy $\mathrm{R}$, et al. Detection of viruses in myocardial tissues by polymerase chain reaction. evidence of adenovirus as a common cause of myocarditis in children and adults. J Am Coll Cardiol 2003;42:466-72.

21. Matsumori A, Yutani C, Ikeda Y, Kawai S, Sasayama S. Hepatitis C virus from the hearts of patients with myocarditis and cardiomyopathy. Lab Invest 2000;80:1137-42.

22. Omura T, Yoshiyama M, Hayashi T, Nishiguchi S, Kaito M, Horiike S, et al. Core protein of hepatitis $\mathrm{C}$ virus induces cardiomyopathy. Circ Res 2005;96:148-50.

23. Wink K, Schmitz H. Cytomegalovirus myocarditis. Am Heart J 1980; 100:667-72.

24. Chen J, Han Z, Wu H, Xu W, Yu D, Zhang Y. A large-scale outbreak of echovirus 30 in Gansu Province of China in 2015 and its phylodynamic characterization. Front Microbiol 2020;11:1137.

25. Rohayem J, Dinger J, Fischer R, Klingel K, Kandolf R, Rethwilm A. Fatal myocarditis associated with acute parvovirus B19 and human herpesvirus 6 coinfection. J Clin Microbiol 2001;39:4585-7.

26. Watanabe M, Panetta GL, Piccirillo F, Spoto S, Myers J, Serino FM, et al. Acute Epstein-Barr related myocarditis: an unusual but life-threatening disease in an immunocompetent patient. J Cardiol Cases 2020;21:13740.

27. Karatolios K, Maisch B, Pankuweit S. Suspected inflammatory cardiomyopathy. Prevalence of Borrelia burgdorferi in endomyocardial biopsies with positive serological evidence. Herz 2015;40 Suppl 1:91-5.

28. Marin-Neto JA, Cunha-Neto E, Maciel BC, Simoes MV. Pathogenesis of chronic Chagas heart disease. Circulation 2007;115:1109-23.

29. Gravanis MB, Hertzler GL, Franch RH, Stacy LD, Ansari AA, Kanter KR, et al. Hypersensitivity myocarditis in heart transplant candidates. J Heart Lung Transplant 1991;10(5 Pt 1):688-97.

30. Mevorach D, Anis E, Cedar N, Bromberg M, Haas EJ, Nadir E, et al. Myocarditis after BNT162b2 mRNA vaccine against Covid-19 in Israel. NEngl J Med 2021;385:2140-9.

31. Barda N, Dagan N, Balicer RD. BNT162b2 mRNA Covid-19 vaccine in a nationwide mass vaccination setting. Reply. N Engl J Med 2021;384:
1970.

32. Arness MK, Eckart RE, Love SS, Atwood JE, Wells TS, Engler RJ, et al. Myopericarditis following smallpox vaccination. Am J Epidemiol 2004;160:642-51.

33. Halsell JS, Riddle JR, Atwood JE, Gardner P, Shope R, Poland GA, et al. Myopericarditis following smallpox vaccination among vaccinia-naive US military personnel. JAMA 2003;289:3283-9.

34. Park H, Yun KW, Kim KR, Song SH, Ahn B, Kim DR, et al. Epidemiology and clinical features of myocarditis/pericarditis before the introduction of mRNA COVID-19 vaccine in Korean children: a multicenter study. J Korean Med Sci. 2021;36:e232.

35. Kim J, Cho MJ. Acute myocarditis in children: a 10-year nationwide study (2007-2016) based on the Health Insurance Review and Assessment Service Database in Korea. Korean Circ J 2020;50:1013-22.

36. Seok H, Oh JH. Hypertrophic cardiomyopathy in infants from the perspective of cardiomyocyte maturation. Korean Circ J 2021;51:73351.

37. Bergmann O, Zdunek S, Felker A, Salehpour M, Alkass K, Bernard S, et al. Dynamics of cell generation and turnover in the human heart. Cell 2015;161:1566-75.

38. Ammirati E, Veronese G, Bottiroli M, Wang DW, Cipriani M, Garascia A, et al. Update on acute myocarditis. Trends Cardiovasc Med 2021;31:3709.

39. Verdonschot J, Hazebroek M, Merken J, Debing Y, Dennert R, BrunnerLa Rocca HP, et al. Relevance of cardiac parvovirus B19 in myocarditis and dilated cardiomyopathy: review of the literature. Eur J Heart Fail 2016;18:1430-41.

40. Rose NR. Learning from myocarditis: mimicry, chaos and black holes. F1000Prime Rep 2014;6:25.

41. Bratincsak A, El-Said HG, Bradley JS, Shayan K, Grossfeld PD, Cannavino CR. Fulminant myocarditis associated with pandemic H1N1 influenza A virus in children. J Am Coll Cardiol 2010;55:928-9.

42. Wang D, Hu B, Hu C, Zhu F, Liu X, Zhang J, et al. Clinical characteristics of 138 hospitalized patients with 2019 novel coronavirus-infected pneumonia in Wuhan, China. JAMA 2020;323:1061-9.

43. Guo T, Fan Y, Chen M, Wu X, Zhang L, He T, et al. Cardiovascular implications of fatal outcomes of patients with coronavirus disease 2019 (COVID-19). JAMA Cardiol 2020;5:811-8.

44. Tavazzi G, Pellegrini C, Maurelli M, Belliato M, Sciutti F, Bottazzi A, et al. Myocardial localization of coronavirus in COVID-19 cardiogenic shock. Eur J Heart Fail 2020;22:911-5.

45. Tschope C, Cooper LT, Torre-Amione G, Van Linthout S. Management of myocarditis-related cardiomyopathy in adults. Circ Res 2019;124:156883.

46. Mahmood SS, Fradley MG, Cohen JV, Nohria A, Reynolds KL, Heinzerling LM, et al. Myocarditis in patients treated with immune checkpoint inhibitors. J Am Coll Cardiol 2018;71:1755-64.

47. Haslam A, Prasad V. Estimation of the percentage of US patients with cancer who are eligible for and respond to checkpoint inhibitor immunotherapy drugs. JAMA Netw Open 2019;2:e192535.

48. Costanzo-Nordin MR, Reap EA, O'Connell JB, Robinson JA, Scanlon PJ. A nonsteroid anti-inflammatory drug exacerbates Coxsackie B3 murine myocarditis. J Am Coll Cardiol 1985;6:1078-82.

49. Semmler D, Blank R, Rupprecht H. Complete AV block in Lyme carditis: an important differential diagnosis. Clin Res Cardiol 2010;99:519-26.

50. Mirabel M, Luyt CE, Leprince P, Trouillet JL, Leger P, Pavie A, et al. Outcomes, long-term quality of life, and psychologic assessment of fulminant myocarditis patients rescued by mechanical circulatory support. Crit Care Med 2011;39:1029-35.

51. Rajagopal SK, Almond CS, Laussen PC, Rycus PT, Wypij D, Thiagarajan RR. Extracorporeal membrane oxygenation for the support of infants, children, and young adults with acute myocarditis: a review of the Extracorporeal Life Support Organization registry. Crit Care Med 2010; 38:382-7.

52. Hufnagel G, Pankuweit S, Richter A, Schonian U, Maisch B. The European Study of Epidemiology and Treatment of Cardiac Inflammatory Diseases (ESETCID). First epidemiological results. Herz 2000;25: 
279-85.

53. McNamara DM, Holubkov R, Starling RC, Dec GW, Loh E, TorreAmione $\mathrm{G}$, et al. Controlled trial of intravenous immune globulin in recent-onset dilated cardiomyopathy. Circulation 2001;103:2254-9.

54. Drucker NA, Colan SD, Lewis AB, Beiser AS, Wessel DL, Takahashi M, et al. Gamma-globulin treatment of acute myocarditis in the pediatric population. Circulation 1994;89:252-7.

55. Bulut D, Scheeler M, Wichmann T, Borgel J, Miebach T, Mugge A. Effect of protein A immunoadsorption on $\mathrm{T}$ cell activation in patients with inflammatory dilated cardiomyopathy. Clin Res Cardiol 2010;99:633-8.

56. Wojnicz R, Nowalany-Kozielska E, Wojciechowska C, Glanowska G, Wilczewski P, Niklewski T, et al. Randomized, placebo-controlled study for immunosuppressive treatment of inflammatory dilated cardiomyopathy: two-year follow-up results. Circulation 2001;104:39-45.

57. Fairweather D, Kaya Z, Shellam GR, Lawson CM, Rose NR. From infection to autoimmunity. J Autoimmun 2001;16:175-86.

58. Lv H, Havari E, Pinto S, Gottumukkala RV, Cornivelli L, Raddassi K, et al. Impaired thymic tolerance to alpha-myosin directs autoimmunity to the heart in mice and humans. J Clin Invest 2011;121:1561-73.

59. Miric M, Vasiljevic J, Bojic M, Popovic Z, Keserovic N, Pesic M. Longterm follow up of patients with dilated heart muscle disease treated with human leucocytic interferon alpha or thymic hormones initial results. Heart 1996;75:596-601.

60. Gullestad L, Aass H, Andreassen AK, Ihlen H, Simonsen S, Kjekshus J, et al. Immunomodulating treatment in advanced heart failure--effect of intravenous immunoglobulin. Tidsskr Nor Laegeforen 2001;121:19027.

61. Frustaci A, Chimenti C, Calabrese F, Pieroni M, Thiene G, Maseri A. Immunosuppressive therapy for active lymphocytic myocarditis: virological and immunologic profile of responders versus nonresponders. Circulation 2003;107:857-63.

62. Dennert R, Velthuis S, Schalla S, Eurlings L, van Suylen RJ, van Paassen $\mathrm{P}$, et al. Intravenous immunoglobulin therapy for patients with idiopathic cardiomyopathy and endomyocardial biopsy-proven high PVB19 viral load. Antivir Ther 2010;15:193-201.

63. Baughman KL. Diagnosis of myocarditis: death of Dallas criteria. Circulation 2006;113:593-5.

64. Matsumori A, Igata H, Ono K, Iwasaki A, Miyamoto T, Nishio R, et al. High doses of digitalis increase the myocardial production of proinflam. matory cytokines and worsen myocardial injury in viral myocarditis: a possible mechanism of digitalis toxicity. Jpn Circ J 1999;63:934-40.

65. Xiao J, Shimada M, Liu W, Hu D, Matsumori A. Anti-inflammatory effects of eplerenone on viral myocarditis. Eur J Heart Fail 2009;11:34953.

66. Wang WZ, Matsumori A, Yamada T, Shioi T, Okada I, Matsui S, et al. Beneficial effects of amlodipine in a murine model of congestive heart failure induced by viral myocarditis. A possible mechanism through inhibition of nitric oxide production. Circulation 1997;95:245-51.

67. Ha M, Kim VN. Regulation of microRNA biogenesis. Nat Rev Mol Cell Biol 2014;15:509-24.

68. O'Brien J, Hayder H, Zayed Y, Peng C. Overview of MicroRNA biogenesis, mechanisms of actions, and circulation. Front Endocrinol (Lausanne) 2018;9:402.

69. Zhou SS, Jin JP, Wang JQ, Zhang ZG, Freedman JH, Zheng Y, et al. miRNAS in cardiovascular diseases: potential biomarkers, therapeutic targets and challenges. Acta Pharmacol Sin 2018;39:1073-84.

70. van Rooij E, Kauppinen S. Development of microRNA therapeutics is coming of age. EMBO Mol Med 2014;6:851-64.

71. Callis TE, Chen JF, Wang DZ. MicroRNAs in skeletal and cardiac muscle development. DNA Cell Biol 2007;26:219-25.

72. Kaur A, Mackin ST, Schlosser K, Wong FL, Elharram M, Delles C, et al. Systematic review of microRNA biomarkers in acute coronary syndrome and stable coronary artery disease. Cardiovasc Res 2020;116:1113-24.

73. Viereck J, Thum T. Circulating noncoding RNAs as biomarkers of cardiovascular disease and injury. Circ Res 2017;120:381-99.

74. Grueter CE, van Rooij E, Johnson BA, DeLeon SM, Sutherland LB, Qi $\mathrm{X}$, et al. A cardiac microRNA governs systemic energy homeostasis by regulation of MED13. Cell 2012;149:671-83.

75. Heymans S, Eriksson U, Lehtonen J, Cooper LT Jr. The quest for new approaches in myocarditis and inflammatory cardiomyopathy. J Am Coll Cardiol 2016;68:2348-64.

76. Corsten MF, Papageorgiou A, Verhesen W, Carai P, Lindow M, Obad S, et al. MicroRNA profiling identifies microRNA-155 as an adverse mediator of cardiac injury and dysfunction during acute viral myocarditis. Circ Res 2012;111:415-25.

77. Yan L, Hu F, Yan X, Wei Y, Ma W, Wang Y, et al. Inhibition of microRNA-155 ameliorates experimental autoimmune myocarditis by modulating Th17/Treg immune response. J Mol Med (Berl) 2016;94: 1063-79.

78. Zhang Y, Zhang M, Li X, Tang Z, Wang X, Zhong M, et al. Silencing microRNA-155 attenuates cardiac injury and dysfunction in viral myocarditis via promotion of $\mathrm{m} 2$ phenotype polarization of macrophages. Sci Rep 2016;6:22613.

79. Navarro IC, Ferreira FM, Nakaya HI, Baron MA, Vilar-Pereira G, Pereira IR, et al. MicroRNA transcriptome profiling in heart of trypanosoma cruzi-infected mice: parasitological and cardiological outcomes. PLoS Negl Trop Dis 2015;9:e0003828.

80. Zhao S, Yang G, Liu PN, Deng YY, Zhao Z, Sun T, et al. miR-590-3p is a Novel MicroRNA in myocarditis by targeting nuclear factor kappa-B in vivo. Cardiology 2015;132:182-8.

81. Kuehl U, Lassner D, Gast M, Stroux A, Rohde M, Siegismund C, et al. Differential cardiac microRNA expression predicts the clinical course in human enterovirus cardiomyopathy. Circ Heart Fail 2015;8:605-18.

82. Corsten MF, Dennert R, Jochems S, Kuznetsova T, Devaux Y, Hofstra L, et al. Circulating microRNA-208b and microRNA-499 reflect myocardial damage in cardiovascular disease. Circ Cardiovasc Genet 2010;3:499506.

83. Devaux Y, Vausort M, Goretti E, Nazarov PV, Azuaje F, Gilson G, et al. Use of circulating microRNAs to diagnose acute myocardial infarction. Clin Chem 2012;58:559-67.

84. Corsten MF, Heggermont W, Papageorgiou AP, Deckx S, Tijsma A, Verhesen W, et al. The microRNA-221/-222 cluster balances the antiviral and inflammatory response in viral myocarditis. Eur Heart J 2015;36: 2909-19.

85. Heymans S, Corsten MF, Verhesen W, Carai P, van Leeuwen RE, Custers $\mathrm{K}$, et al. Macrophage microRNA-155 promotes cardiac hypertrophy and failure. Circulation 2013;128:1420-32.

86. Blanco-Dominguez R, Sanchez-Diaz R, de la Fuente H, JimenezBorreguero LJ, Matesanz-Marin A, Relano M, et al. A novel circulating microRNA for the detection of acute myocarditis. N Engl J Med 2021; 384:2014-27.

87. Stephenson ML, Zamecnik PC. Inhibition of Rous sarcoma viral RNA translation by a specific oligodeoxyribonucleotide. Proc Natl Acad Sci US A 1978;75:285-8.

88. Kristen AV, Ajroud-Driss S, Conceicao I, Gorevic P, Kyriakides T, Obici L. Patisiran, an RNAi therapeutic for the treatment of hereditary transthyretin-mediated amyloidosis. Neurodegener Dis Manag 2019; 9:5-23.

89. Adams D, Gonzalez-Duarte A, O'Riordan WD, Yang CC, Ueda M, Kristen AV, et al. Patisiran, an RNAi therapeutic, for hereditary transthyretin amyloidosis. NEngl J Med 2018;379:11-21.

90. Hanna J, Hossain GS, Kocerha J. The potential for microRNA therapeutics and clinical research. Front Genet 2019;10:478.

91. Crooke ST, Witztum JL, Bennett CF, Baker BF. RNA-targeted therapeutics. Cell Metab 2018;27:714-39.

92. Setten RL, Rossi JJ, Han SP. The current state and future directions of RNAi-based therapeutics. Nat Rev Drug Discov 2019;18:421-46.

93. Hu B, Zhong L, Weng Y, Peng L, Huang Y, Zhao Y, et al. Therapeutic siRNA: state of the art. Signal Transduct Target Ther 2020;5:101.

94. Krutzfeldt J, Rajewsky N, Braich R, Rajeev KG, Tuschl T, Manoharan $\mathrm{M}$, et al. Silencing of microRNAs in vivo with 'antagomirs'. Nature 2005;438:685-9.

95. Lucas T, Bonauer A, Dimmeler S. RNA therapeutics in cardiovascular disease. Circ Res 2018;123:205-20. 
96. Abplanalp WT, Fischer A, John D, Zeiher AM, Gosgnach W, Darville H, et al. Efficiency and target derepression of anti-miR-92a: results of a first in human study. Nucleic Acid Ther 2020;30:335-45.

97. Taubel J, Hauke W, Rump S, Viereck J, Batkai S, Poetzsch J, et al. Novel antisense therapy targeting microRNA-132 in patients with heart failure: results of a first-in-human Phase $1 \mathrm{~b}$ randomized, double-blind, placebocontrolled study. Eur Heart J 2021;42:178-88.

98. Li T, Ding ZL, Zheng YL, Wang W. MiR-484 promotes non-small-cell lung cancer (NSCLC) progression through inhibiting Apaf- 1 associated with the suppression of apoptosis. Biomed Pharmacother 2017;96:15364.

99. Kumarswamy R, Volkmann I, Beermann J, Napp LC, Jabs O, Bhayadia R, et al. Vascular importance of the miR-212/132 cluster. Eur Heart J 2014;35:3224-31.

100. Foinquinos A, Batkai S, Genschel C, Viereck J, Rump S, Gyongyosi M, et al. Preclinical development of a miR-132 inhibitor for heart failure treatment. Nat Commun 2020;11:633.

101. van Rooij E, Sutherland LB, Liu N, Williams AH, McAnally J, Gerard $\mathrm{RD}$, et al. A signature pattern of stress-responsive microRNAs that can evoke cardiac hypertrophy and heart failure. Proc Natl Acad Sci U S A 2006;103:18255-60.

102. Ho BC, Yu SL, Chen JJ, Chang SY, Yan BS, Hong QS, et al. Enterovirusinduced miR-141 contributes to shutoff of host protein translation by targeting the translation initiation factor eIF4E. Cell Host Microbe 2011;9:58-69.

103. Tong L, Lin L, Wu S, Guo Z, Wang T, Qin Y, et al. MiR-10a* up-regulates coxsackievirus B3 biosynthesis by targeting the 3D-coding sequence. Nucleic Acids Res 2013;41:3760-71.

104. Liao Y, Chen KH, Dong XM, Fang Y, Li WG, Huang GY, et al. A role of pre-mir-10a coding region variant in host susceptibility to coxsackie virus-induced myocarditis. Eur Rev Med Pharmacol Sci 2015;19:35007.

105. Xu HF, Ding YJ, Shen YW, Xue AM, Xu HM, Luo CL, et al. MicroRNA1 represses Cx43 expression in viral myocarditis. Mol Cell Biochem 2012;362:141-8.

106. Ye X, Hemida MG, Qiu Y, Hanson PJ, Zhang HM, Yang D. MiR-126 promotes coxsackievirus replication by mediating cross-talk of ERK1/2 and Wnt/beta-catenin signal pathways. Cell Mol Life Sci 2013;70:463144.

107. Wu J, Shen L, Chen J, Xu H, Mao L. The role of microRNAs in enteroviral infections. Braz J Infect Dis 2015; 19:510-6.

108. Sun P, Wang N, Zhao P, Wang C, Li H, Chen Q, et al. Circulating exosomes control CD4(+) $\mathrm{T}$ cell immunometabolic functions via the transfer of mir-142 as a novel mediator in myocarditis. Mol Ther 2020;28:2605-20.

How to cite this article: $\mathrm{Oh} \mathrm{JH,} \mathrm{Kim} \mathrm{GB,} \mathrm{Seok} \mathrm{H.} \mathrm{Implication}$ of microRNA as a potential biomarker of myocarditis. Clin Exp Pediatr 2023:65:230-8. https://doi.org/10.3345/cep.2021.01802 